\title{
VISUALIZING LIFE IN AN INFORMAL SETTLEMENT OF SOUTH AFRICA USING WEB MAPS AND STORY MAPS
}

\author{
A. Z. Mdleleni*, V. Rautenbach, S. Coetzee \\ Department of Geography, Geoinformatics and Meteorology, University of Pretoria, Pretoria, South Africa \\ azile.mdleleni@tuks.co.za, (victoria.rautenbach, serena.coetzee)@up.ac.za
}

\author{
Commission IV, WG IV/9
}

KEY WORDS: participatory GIS, community mapping, informal settlement, web maps, story maps

\begin{abstract}
:
Informal settlements are often not mapped, and only anecdotal evidence is commonly found on the activities that take place daily within these settlements. To address, this lack of information we followed a participatory GIS (PGIS) approach to mapping the daily struggles of individuals in the informal settlement of Alaska, Mamelodi, in Pretoria, South Africa. We interviewed twelve community members and started to analyse the data, but the question arises, how do we visualize and communicate the results? We decided to make use of web maps and story maps, and we implemented them both in Esri ArcGIS Online and in Mapbox. In this paper, we present the results of an evaluation of ArcGIS Online and Mapbox for creating web maps and story maps for PGIS projects. A list of evaluation criteria was developed based on literature and our experience. The results show that both ArcGIS Online and Mapbox are suitable options for creating web maps and story maps, but that they have different barriers to entry. We also found that story maps are superior in some cases to web maps for creating visualizations for PGIS projects as they provide a narrative with which the user can connect and a more immersive environment than web maps.
\end{abstract}

\section{INTRODUCTION}

Informal settlements are dynamic and ever-changing in nature and are generally characterised by a lack of service delivery (Kostof, 1993; Mason et al., 1997; Huchzermeyer and Karam, 2006). As a result, the settlement dwellers are faced with many daily struggles that impact on their lives, such as limited access to public transport, public services, health care and internet connectivity. To gain spatial knowledge about informal settlements, an approach called participatory GIS (PGIS) can be employed, which is used to co-produce spatial knowledge with a community about the community (Dunn, 2007; McCall \& Dunn, 2012). This open line of communication is more likely to result in community buy-in and support as a clearer understanding of community needs is established. In turn, it allows stakeholders to gain a better understanding of the spatial nature of the daily activities and struggles in informal settlements (Rautenbach et al., 2015). This is essential when presenting the community's case to stakeholders in local governments, non-governmental organisations (NGOs) and the private sector. Once data has been collected using PGIS strategies, such as questionnaires, semistructured interviews or focus groups, the question arises, how do we visualize and communicate the results?

In our study, we investigated the daily activities and struggles in the informal settlements to reveal information previously unknown to local government, especially in the South African context, because such qualitative information is not included in national and local socio-demographic datasets (e.g. Statistics South Africa's Census data). The information can inform the planning of interventions for effective in-situ upgrading in an informal settlement.

We used convenience sampling and twelve community members were selected from the Alaska informal settlement in Mamelodi East, City of Tshwane. We focussed on the daily struggles of individuals in the informal settlement. The interviews were recorded, and locations indicated in response to interview questions were marked on aerial photographs of the area. The locations were later digitised as individual layers (e.g. water collection points and transportation nodes) and then analysed. The results of the analysis were visualised in two ways, namely as web maps and as story maps, and we implemented both in ArcGIS Online and in Mapbox.

In this paper, we present the results of a comparison of two popular web mapping and story map applications. Firstly, we present a list of criteria that should be considered when selecting such applications in PGIS projects. We then present our evaluation of the Esri ArcGIS Online and Mapbox. The subsequent discussion reflects on the results and our experiences with creating web maps and story maps to communicate the daily struggles. The remainder of this paper is structured as follows: in Section 2, the evaluation criteria are described; in Section 3, we present the applications that will be evaluated; evaluation results are presented and discussed in Section 4; and we conclude in the last section.

\section{EVALUATION CRITERIA}

The outcome of the PGIS process is visualizations that are given back to the community. In this project, we envision that the community would be able to use the visualizations to communicate with local government and other stakeholders to improve their quality of life.

These visualizations should be user friendly and clean to ensure that the community members can use the visualizations optimally (Rambaldi et al, 2006; Al-Kodmany, 2010; Sheehan, 2013). Interactivity and the use of multimedia resources are important considerations as this engages the community and provides a more immersive experience and an additional level of realism

* Corresponding author 
(Al-Kodmany, 2010; McCall \& Dunn, 2012). Lastly, the visualizations should be available online to ensure that a large audience can be reached. Based on these characteristics, we decided that web maps and story maps would be the best kind of visualizations to design.

According to Sheehan (2013), cost-effectiveness, offline availability and the amount of specialist training needed to operate the system have to be considered when it comes to web maps. We created web maps with the main purpose to communicate with community members to empower them. Although hard copy maps could also be used, web maps are accessible to a wider audience and allow community members to view the information on their mobile devices.

Story maps are a combination of geospatial data, multimedia and text to help with the visualisation of events (Scott et al. 2016). Story maps were created to depict the narrative of community members' daily activities and struggles in the settlement.

Based on these characteristics and our experience, we established a list of evaluation criteria against which the selected applications for the design and development of web maps and story maps can be evaluated. Refer to the criteria presented in Table 1.

\begin{tabular}{|c|c|}
\hline Criteria & Description \\
\hline \multicolumn{2}{|l|}{ 1. General criteria } \\
\hline $\begin{array}{l}\text { 1.1. Documentation and } \\
\text { support available }\end{array}$ & $\begin{array}{l}\text { The documentation and additional avenues available to users for support, such as tutorials, forums } \\
\text { and mailing lists. }\end{array}$ \\
\hline $\begin{array}{l}\text { 1.2. Ease of integration with } \\
\text { other applications }\end{array}$ & $\begin{array}{l}\text { Built-in capabilities to facilitate integration with other applications. For example, the ability to use } \\
\text { data from a PostGIS database or use vector tiles from GeoServer as the base map. }\end{array}$ \\
\hline $\begin{array}{l}\text { 1.3. Ease of extending the } \\
\text { application }\end{array}$ & $\begin{array}{l}\text { Refers to the effort required to add additional functionality to the applications (i.e. web map or } \\
\text { story map). }\end{array}$ \\
\hline 1.4. Usability & Refers to the user-friendliness and general intuitiveness of the applications. \\
\hline 1.5. License & $\begin{array}{l}\text { Refers to whether the license under which the application is available, e.g. open source, freeware } \\
\text { or proprietary. If the application is available under a proprietary license, what functionalities and } \\
\text { storage are available under the free tier, if a free tier is available. }\end{array}$ \\
\hline \multicolumn{2}{|l|}{ 2. Web map criteria } \\
\hline 2.1. Base maps & $\begin{array}{l}\text { Refers to whether vector and/or raster tiles are available as the base map and the number of base } \\
\text { map options. Vector tiles allow the user to customize every aspect of the base map, where raster } \\
\text { tiles not editable. }\end{array}$ \\
\hline 2.2. Data storage & $\begin{array}{l}\text { The format in which data is stored within the application, for example within a database or as a } \\
\text { layer. }\end{array}$ \\
\hline 2.3. Symbolization & The flexibility in the design of map symbols and a variety of thematic map types available. \\
\hline $\begin{array}{l}\text { 2.4. General customizability } \\
\text { of the web map }\end{array}$ & $\begin{array}{l}\text { The ability to add or remove certain map elements or other objects (e.g. text or photographs) to } \\
\text { the web map. This also includes the search or filter functionality and adding popups to features. }\end{array}$ \\
\hline $\begin{array}{l}\text { 2.5. Export or sharing } \\
\text { options }\end{array}$ & $\begin{array}{l}\text { Refers to the format in which the web map can be shared and if users would need an account or } \\
\text { any software to view the web map. Additionally, does the application allow the export of the web } \\
\text { map for hosting on own or external servers. }\end{array}$ \\
\hline \multicolumn{2}{|l|}{ 3. Story map criteria } \\
\hline 3.1. Base maps & $\begin{array}{l}\text { Refers to whether vector and/or raster tiles are available as the base map and the number of base } \\
\text { map options. Vector tiles allow the user to customize every aspect of the base map, where raster } \\
\text { tiles not editable. }\end{array}$ \\
\hline 3.2. Data storage & $\begin{array}{l}\text { The format in which data is stored within the application, for example within a database or as a } \\
\text { layer. }\end{array}$ \\
\hline $\begin{array}{l}\text { 3.3. Layout and movement } \\
\text { options available }\end{array}$ & $\begin{array}{l}\text { Refers to whether the application provides pre-set layouts and how much these can be changed. } \\
\text { With this, the customizability of the movements or transitions between "slides" in the story map. }\end{array}$ \\
\hline $\begin{array}{l}\text { 3.4. Ability to embed } \\
\text { external resources }\end{array}$ & $\begin{array}{l}\text { The ability to seamlessly embed external resources, such as a web map or story map from a } \\
\text { different application. }\end{array}$ \\
\hline 3.5. Sharing options & $\begin{array}{l}\text { Refers to the format in which the web map can be shared and if users would need an account or } \\
\text { any software to view the web map. }\end{array}$ \\
\hline
\end{tabular}

Table 1. Evaluation criteria for choosing tools to design web map and story maps for PGIS

\section{OVERVIEW OF ESRI AND MAPBOX}

There are various web mapping applications available. At present, Esri ArcGIS Online and Mapbox are among the most widely used. In this section, we provide a brief overview of both Esri ArcGIS Online and Mapbox.

\subsection{Esri ArcGIS Online for web maps and story maps}

Esri is one of the oldest software providers in the geospatial sphere with the largest market share of approximately $43 \%$ globally (Esri, 2015). The Esri suite consists of various applications which operate on desktop, server, and mobile platforms. The Esri ArcGIS Online and Esri Story Maps were used for the design and the development of the web maps and story maps, and ArcGIS Web Appbuilder were used to publish the final visualizations.

ArcGIS Online is cloud-based geospatial mapping software that allows users to analyse data, and create and share maps while collaborating (ArcGIS Online, 2020). The ArcGIS Online provides integration with the entire Esri suite, for example, Survey123 can be used to collect data in the field and map the data immediately in a web map. ArcGIS Online is designed with non-expert users in mind. When a new dataset is loaded, the user is presented with suggested thematic map types. This makes it easier for the user to create high-quality web maps without the need to write any code. 
Esri Story Maps provide a way to combine map data with narrative text, images and multimedia content (Esri Classic Story Maps, 2020). To make the process seamless for the user, the user is presented with various pre-set layouts, namely, Story Map Basic, Tour, Journal, Cascade, Series, Shortlist, and Swipe and Spyglass. The focus of Esri Story Maps is on creating an immersive experience in a codeless environment.

\subsection{Mapbox applications for web maps and story maps}

Mapbox was established in 2010 and has exponentially grown in popularity over the past 5 years for their open source custom designed maps for the web and mobile (Mapbox, 2020). In late 2019, Mapbox released their interactive storytelling library for creating story maps.

Mapbox Studio and Mapbox GL JS are the two main components for creating web maps with Mapbox. Mapbox Studio provides users with a user interface for managing their geospatial data, creating custom maps, tilesets and visualizations (add reference to website). Mapbox Studio is a codeless environment for creating maps, but it might be difficult for beginners to use with the wide range of customization options available. Mapbox GL JS is a JavaScript library that uses WebGL to render interactive maps from vector tiles and Mapbox styles.

Mapbox Interactive Storytelling is a low-code template for developing story maps. Interactive Storytelling is still in its second release and has limited functionalities. However, it uses JavaScript and tilesets from Mapbox Studio for the design which allows for some customizability.

\section{RESULTS AND DISCUSSION}

Table 2 provides the results of our evaluation, based on our experiences with implementing web maps and story maps for the community as part of the PGIS project. Subsequently, we reflect on the success of the resulting web maps and story maps to communicate the daily struggles.

\begin{tabular}{|c|c|c|}
\hline Criteria & Esri ArcGIS Online & Mapbox \\
\hline \multicolumn{3}{|l|}{ 1. General criteria } \\
\hline $\begin{array}{l}\text { 1.1. Documentation } \\
\text { and support } \\
\text { available }\end{array}$ & $\begin{array}{l}\text { Detailed and easy to follow documentation and } \\
\text { tutorials. Local Esri distributors also provide } \\
\text { support to individuals who purchased licenses. }\end{array}$ & $\begin{array}{l}\text { Mapbox provides step-by-step guides to create a } \\
\text { web map or story map. Stack Overflow }{ }^{1} \text { (a } \\
\text { question and answer site focused on technical } \\
\text { issues and programming) is useful for resolving } \\
\text { any issues and various GitHub repositories } \\
\text { (hosting for version control using git) provide code } \\
\text { snippets. }\end{array}$ \\
\hline $\begin{array}{l}\text { 1.2. Ease of integration } \\
\text { with other } \\
\text { applications }\end{array}$ & $\begin{array}{l}\text { Third party databases, such as PostgreSQL, can } \\
\text { be used as an input source via ArcGIS Server. } \\
\text { The Esri suite provides data export options that } \\
\text { are interoperable with external applications. } \\
\text { Esri has recently started to release an API or } \\
\text { library for all they applications. This allows } \\
\text { advance users to other libraries and applications. }\end{array}$ & $\begin{array}{l}\text { Mapbox GL JS allows the user to use data } \\
\text { directly from a database, such as PostgreSQL. } \\
\text { However, with Mapbox Studio this is not } \\
\text { possible, and data needs to be loaded onto the } \\
\text { server as GeoJSON. } \\
\text { Mapbox provides various JavaScript libraries that } \\
\text { allow integration with other libraries and } \\
\text { applications. }\end{array}$ \\
\hline $\begin{array}{l}\text { 1.3. Ease of extending } \\
\text { the application }\end{array}$ & $\begin{array}{l}\text { Esri provides an accompanying library for all } \\
\text { their software, for example for creating web maps } \\
\text { advance users can make use of the ArcGIS API } \\
\text { for JavaScript to extent or customize their web } \\
\text { maps. }\end{array}$ & $\begin{array}{l}\text { The license type and availability of JavaScript } \\
\text { libraries allows for easy extension of the } \\
\text { applications within Mapbox. }\end{array}$ \\
\hline 1.4. Usability & $\begin{array}{l}\text { Within the user interface, the Esri applications } \\
\text { are easy to use and suitable for non-experts. This } \\
\text { is achieved by limiting the functionalities that the } \\
\text { user can perform. }\end{array}$ & $\begin{array}{l}\text { Mapbox can be challenging for non-experts as the } \\
\text { user interface is quite advance and provides } \\
\text { numerous functionalities that allows the user to } \\
\text { customize their final visualization. }\end{array}$ \\
\hline 1.5. License & $\begin{array}{l}\text { Proprietary with some open source components. } \\
\text { Esri provides a free tier public account (personal, } \\
\text { non-commercial) that allows the user to create, } \\
\text { store and manage maps, scenes and applications. } \\
\text { Additional storage and functionalities are } \\
\text { available with paid licenses. }\end{array}$ & $\begin{array}{l}\text { Open source. User is however liable to pay for } \\
\text { storage and hosting cost. Mapbox provides a free } \\
\text { tier account with } 50 \text { GB storage, thereafter charges } \\
\text { apply. Mapbox currently do not offer hosting } \\
\text { options for story maps, thus personal hosting is } \\
\text { required which may be a hidden cost. }\end{array}$ \\
\hline \multicolumn{3}{|l|}{ 2. Web map criteria } \\
\hline 2.1. Base maps & $\begin{array}{l}\text { Raster tile base maps are available with twelve } \\
\text { variations. }\end{array}$ & $\begin{array}{l}\text { Raster and vector tiles are available with more } \\
\text { than ten variations. The vector tiles allow the user } \\
\text { to customize the base map to fit the style of their } \\
\text { web map. }\end{array}$ \\
\hline
\end{tabular}

\footnotetext{
${ }^{1} \mathrm{https}: / /$ stackoverflow.com

${ }^{2} \mathrm{https}$ //github.com
} 


\begin{tabular}{|c|c|c|}
\hline 2.2. Data storage & Data is stored as layers in ArcGIS server. & $\begin{array}{l}\text { In Mapbox Studio, GeoJSON files can be loaded } \\
\text { and converted to either raster or vector tile layers. } \\
\text { These are stored on the Mapbox server. }\end{array}$ \\
\hline 2.3. Symbolization & Limited customization is possible. & $\begin{array}{l}\text { Symbolization is very customizable, for example } \\
\text { custom SVGs can be imported and used as icons. }\end{array}$ \\
\hline $\begin{array}{l}\text { 2.4. General } \\
\text { customizability of } \\
\text { the web map }\end{array}$ & $\begin{array}{l}\text { The web map can be customized using pre-sets } \\
\text { that, for example, allow the user to select a } \\
\text { different legend style. }\end{array}$ & $\begin{array}{l}\text { All aspects of the map can be customized using } \\
\text { Mapbox GL JS. }\end{array}$ \\
\hline $\begin{array}{l}\text { 2.5. Export or sharing } \\
\text { options }\end{array}$ & $\begin{array}{l}\text { Once published publicly, the map can be viewed } \\
\text { by anyone who has the URL link or anyone with } \\
\text { access to the publicly shared work. For more } \\
\text { privacy, a web map can be shared within an } \\
\text { organization, but it requires all users to have an } \\
\text { organizational account. }\end{array}$ & $\begin{array}{l}\text { A published web map can be shared using an URL. } \\
\text { Tilesets can also be published and reused within } \\
\text { Mapbox, but also downloaded. }\end{array}$ \\
\hline \multicolumn{3}{|l|}{ 3. Story map criteria } \\
\hline 3.1. Base maps & Four raster base maps are available. & $\begin{array}{l}\text { Six raster base maps are available. With the option } \\
\text { of importing customised styles from Mapbox } \\
\text { Studio. }\end{array}$ \\
\hline 3.2. Data storage & $\begin{array}{l}\text { All files uploaded and the story map is stored on } \\
\text { ArcGIS Server. }\end{array}$ & $\begin{array}{l}\text { The files required and code of the story maps is } \\
\text { stored on the user's own server. }\end{array}$ \\
\hline $\begin{array}{l}\text { 3.3. Layout and } \\
\text { movement options } \\
\text { available }\end{array}$ & $\begin{array}{l}\text { Pre-set layouts (i.e. map journal, map series and } \\
\text { map tour) with some options for customizing. }\end{array}$ & $\begin{array}{l}\text { The layout and movement are restrictive. The user } \\
\text { can only change the positioning of frames and the } \\
\text { angles of the rotating and panning only to a certain } \\
\text { extent. }\end{array}$ \\
\hline $\begin{array}{l}\text { 3.4. Ability to embed } \\
\text { external resources }\end{array}$ & $\begin{array}{l}\text { Uploaded resources can easily be uploaded and } \\
\text { embedded. With websites, a secure connection is } \\
\text { required (https). }\end{array}$ & $\begin{array}{l}\text { Multimedia resources can be embedded easily, as } \\
\text { well as maps and data from a user's existing } \\
\text { Mapbox Studio account. }\end{array}$ \\
\hline 3.5. Sharing options & $\begin{array}{l}\text { Once published publicly, the map can be viewed } \\
\text { by anyone who has the URL link or anyone with } \\
\text { access to the publicly shared work. For more } \\
\text { privacy, a web map can be shared within an } \\
\text { organization, but it requires all users to have an } \\
\text { organizational account. }\end{array}$ & $\begin{array}{l}\text { The code and resources need to be hosted by the } \\
\text { user. This URL can be publicly shared. }\end{array}$ \\
\hline
\end{tabular}

Table 2. Evaluation of Esri ArcGIS Online and Mapbox

From the results presented in Table 2, it is clear that both Esri ArcGIS Online and Mapbox have advantages and disadvantages and both would be suitable to present the results of the PGIS study. Esri ArcGIS Online is most suited for non-experts as the user interface is designed with a lower the barrier to entry. From our experience, it is clear that the interface is designed to be easy to use (see Figure 1a), but the trade-off is that limited functionalities are available. Advanced users would need to make use of the API to customize their visualizations beyond the functions provided by the user interface. Additionally, Esri provides very detailed documentation for all their applications and have a large training catalogue that assists new users to get started.

Mapbox, on the other hand, is more geared towards advanced users as the barrier to entry is quite high. This assumption is supported by the lack of variety in the documentation and tutorials. In most cases, users find answers to their issues on platforms, such as Stack Overflow, or examples in GitHub repositories. When using Mapbox Studio, the user has various options for customizing the look of the visualizations, however, this resulted in a complex user interface that takes time to learn (refer to Figure 1b). 


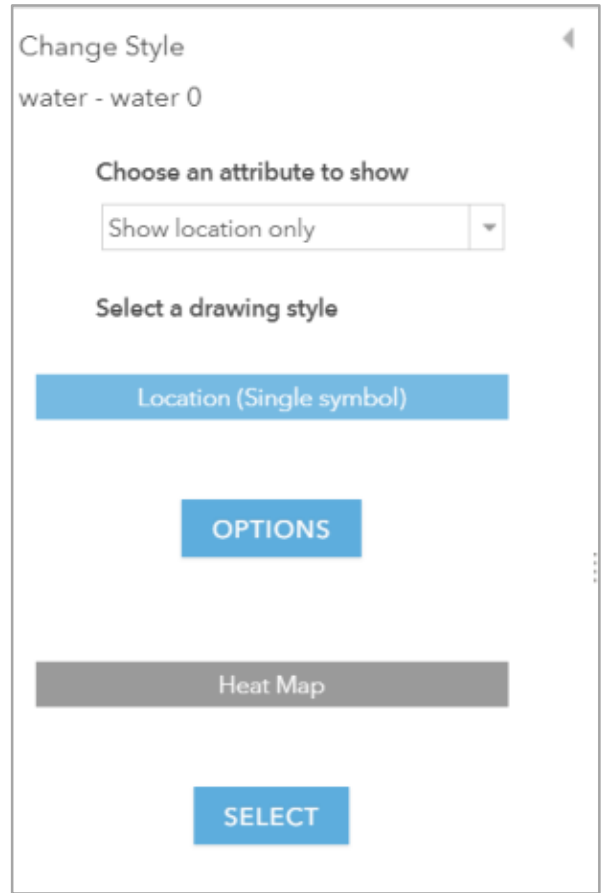

a) Styling options present to the user when a new layer is added to the web map in Esri ArcGIS Online

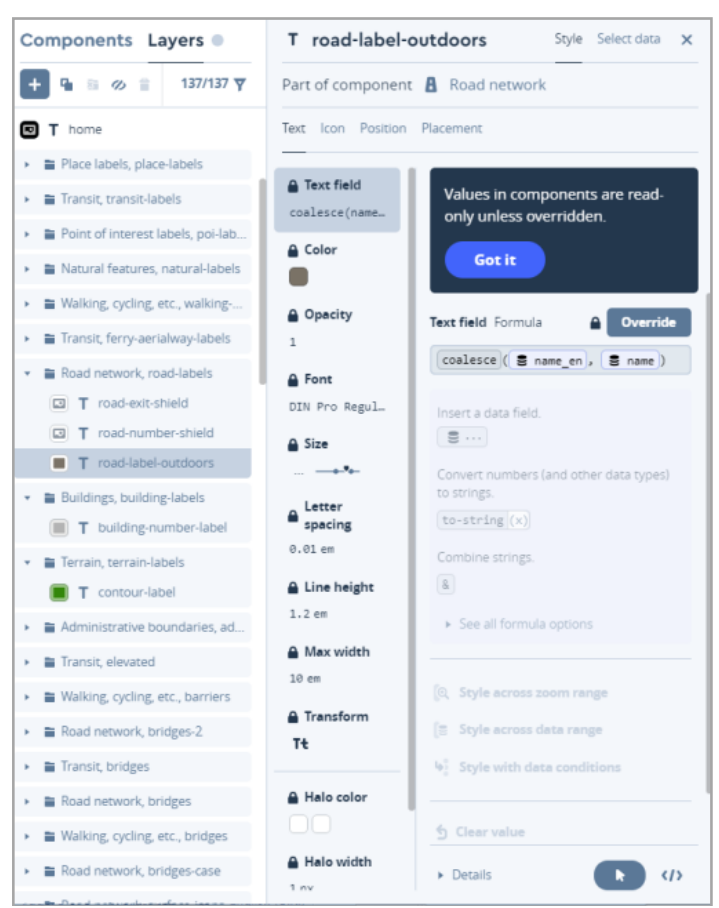

b) Some of the options available to users in Mapbox when editing the style of a layer

Figure 1. User interface presented to the user for styling when adding a new layer to the web map.

When creating a web map, the base map and symbolization are the two criteria where Esri ArcGIS Online and Mapbox differ most. ArcGIS Online provides the user with standard raster base maps, whereas Mapbox allows the user to completely customize the base map with the assistance of vector tiles. Mapbox has six base maps, each with many variations, and these variations can be customised further to fit the style of the user's web map. Another advantage of using vector tiles is that information on the base map can be removed. For example, on OpenStreetMap, some of the building footprints in the informal settlements are mapped, but the data is not complete, thus the user can decide to hide the footprint on their custom base map. However, the user can also edit the data on OpenStreetMap itself to show all the building footprints.

Regarding symbolization, Mapbox again provides the user with a large range of options to customize the web map. In our case, the data displayed on the web map was points. With ArcGIS Online, the user can pick from a pre-set number of icons and little customization is possible in the user interface. Mapbox allows the user to load SVGs that can be used as icons.
When adding map elements to the web map, ArcGIS Online provides the user with map elements, such as a legend or popup to show the attribute information for a point. Some pre-set options are available, but they can be customized using the ArcGIS API for JavaScript. In Mapbox Studio, no map elements are provided, but they can be added with Mapbox GL JS. Refer to Figure 2 for an example of the implementation of ArcGIS Online and Mapbox using their respective user interfaces.

Due to the Esri Story Maps maturity, it has a clear advantage over Mapbox with the number of layout options (with some constraints), a larger number of options for embedding resources (e.g. pictures, videos, and secure websites), and the ability to create the entire story map using the user interface. With Mapbox, the user has to create the story map with JavaScript, as no user interface is available. The last point to consider is the cost of hosting, as with Mapbox the user would have to provide their own hosting facilities. Figure 3 provides an example of the same slide within the Esri applications and Mapbox. 


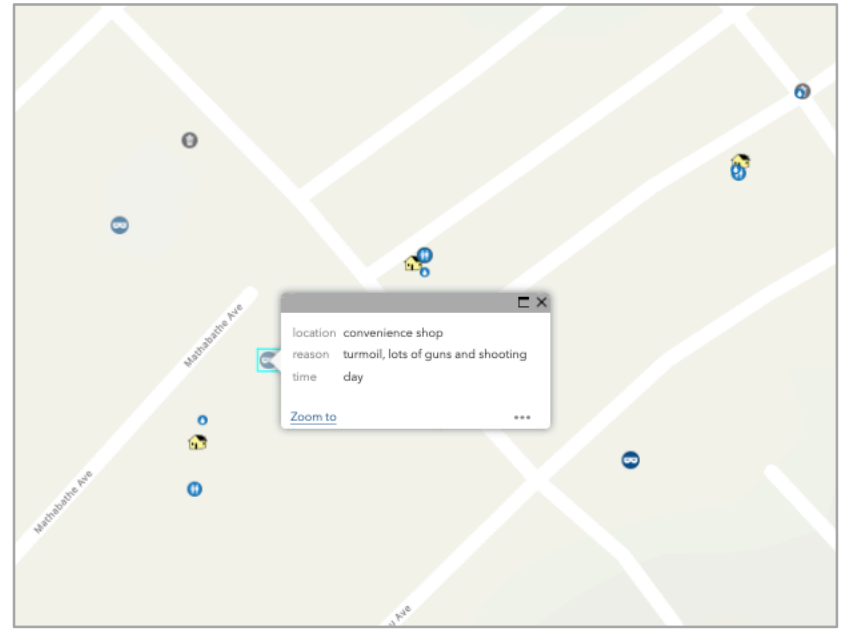

a) ArcGIS Online default icons with an example of the popup when user clicks on icon.

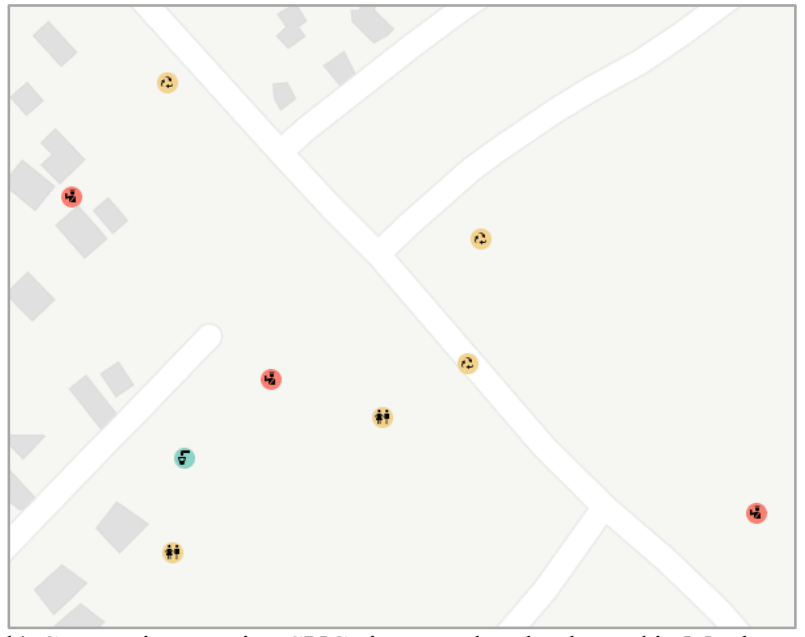

b) Custom icons using SVGs imported and coloured in Mapbox Studio.
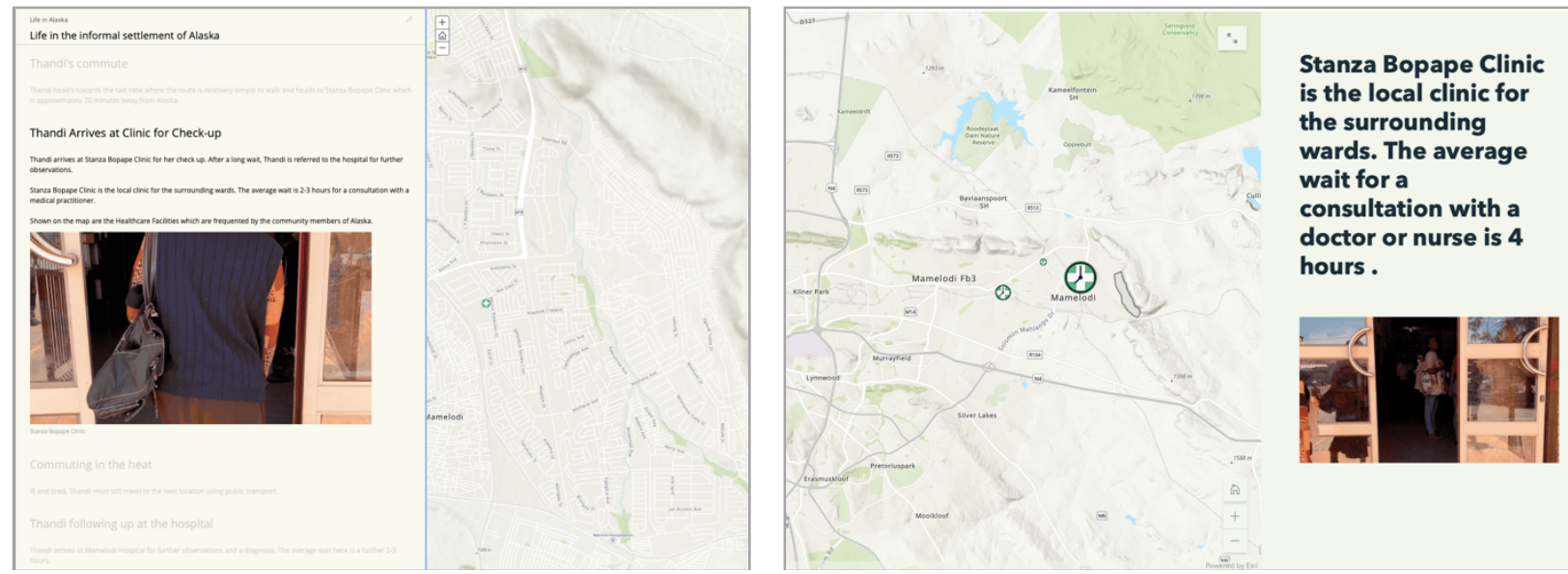

a) Two of the possible layouts possible with Story Maps in Esri Story Maps (left) and ArcGIS StoryMaps (right).

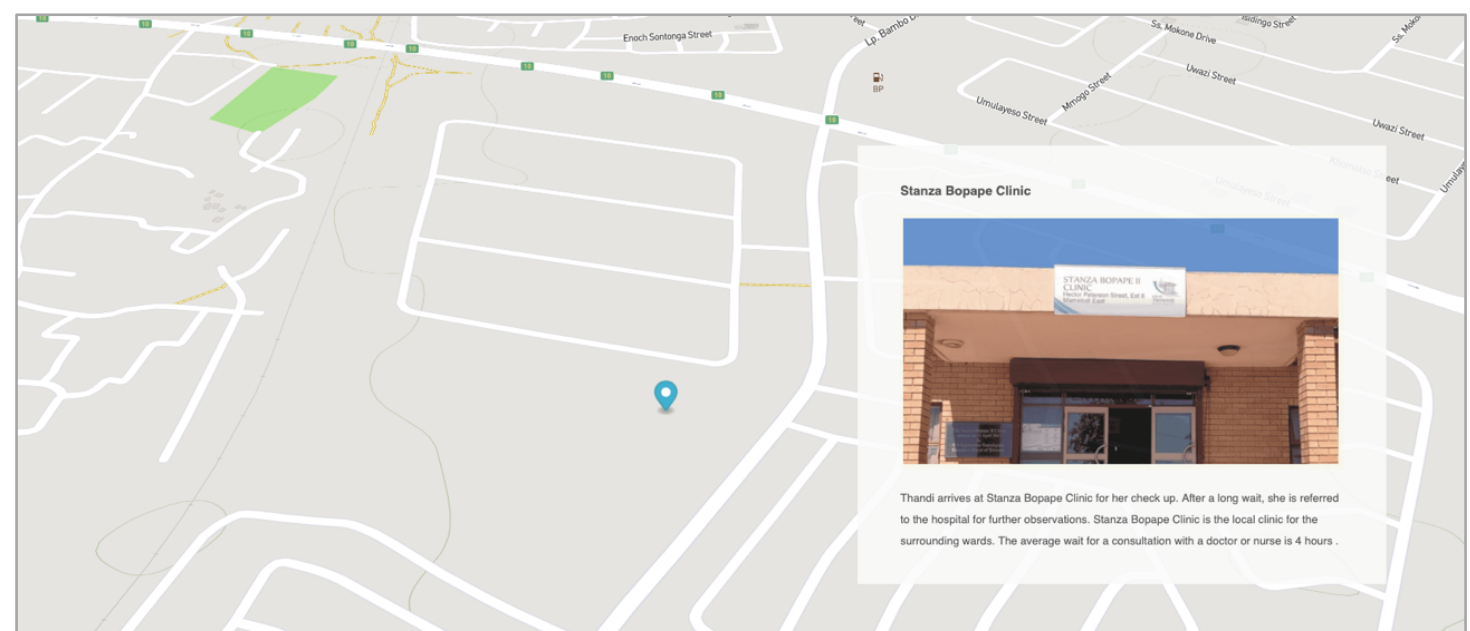

b) The only layout available in Mapbox Interactive Storytelling.

Figure 3. Example of the resulting story map in a) Esri Story Maps and the newer ArcGIS StoryMaps and b) Mapbox

\section{DISCUSSION AND CONCLUSION}

The success of the resulting web maps and story maps to communicate the daily struggles is discussed based on the characteristics described in Section 2.
For the resulting visualization to be successful, it needs to be $u$ ser friendly and the intended user should preferably require as little training as possible to use the visualization. In our opinion, both applications allow researchers to create user-friendly visualizations that require little to no training to use. However, story maps are the more preferred methods of visualizing the data collected in our project (i.e. daily struggles of individuals in 
informal settlements). Story maps present the data in a package that guides the user through the information and conclusions, thus they do not need to synthesize the data.

Interactive visualization creates a more immersive experience as they tend to catch the user's attention and can improve their understanding (DiBase et al., 1992; MacEachren, 1995; Köbben and Yaman, 1996; Rautenbach et al., 2016). Users also tend to enjoy using these types of visualizations more than traditional ones. Web maps are a good way to present a large amount of data as the user can move around and zoom in or out to explore the data. The data can be aggregated in different ways at various zoom levels, for example at a low zoom level the data can be aggregated to the provincial level, this can be followed by municipal boundaries, and on the highest zoom level, the point is not aggregated but shown as individual points. In our project, a small number of points are displayed on the web map in a small area, thus not making full use of the advantages of web maps. Story maps again prove to be the best option to create an interactive and immersive experience. This was aided by the ability to embed multimedia and other sites in the story map. For example, we showed how community members have to walk to collect water at a communal water point (i.e. water tap) using video that was shot in the settlement. These elements in a story map can aid in communicating their struggles and needs to local government better than using traditional maps.

To allow as many community members or stakeholders as possible to view the visualization, it must be available online. We also believe that in the South African context it is important that the visualization can be viewed on a mobile phone. Especially in informal settlements, a limited number of community members have access to personal computers and incompatibility with mobile phones would limit the number of people that can access the visualization. Both applications (i.e. ArcGIS Online and Mapbox) and types of visualization (i.e. web map and story map) can be viewed on a mobile phone and are available online. Access to the internet might still be a barrier.

The cost effectiveness of the application is another important consideration. It is also important that the community member does not need to incur any expenses to view the visualizations. Although Mapbox is an open source application, it might still cost money if the use exceeds the free tier. Esri also provides a free tier but with some limitations on functionalities.

Our research shows that more than one tool is available to effectively communicate information collected via PGIS through mobile and web solutions to relevant stakeholders. However, the type of data and message that you want to communicate should also be considered when deciding between using either or both a web and story map. In further work, we aim to evaluate the usability and performance of the web and story maps with a user study. Such a study has not been done with this type of community and data and would produce valuable guidelines that could guide the development of visualizations for PGIS in the future.

\section{ACKNOWLEDGEMENTS}

This research has been partially supported by the South African National Research Foundation (NRF) Community Engagement Grant for the "Producing Spatial Knowledge with the Community to Empower Them" project.
The authors would also like to thank the Viva Foundation for assisting with the arrangements of the interviews and also hosting us.

\section{REFERENCES}

Al-Kodmany, K., 2010, Visualization Tools and Methods for Participatory Planning and Design, Journal of Urban Technology, 8(2), 1-37.

ArcGIS Online, 2020, ArcGIS Online. Retrieved May 3, 2020, from https://www.arcgis.com

DiBiase, D., MacEachren, A.M., Krygier, J., Reeves, C., 1992. Animation and the Role of Map Design in Scientific Visualization. Cartography and Geographic Information Science 19 (4): pp. 201-214.

Dunn, C. E., 2007, Participatory GIS - A people's GIS?. Progress in Human Geography, 31(5), 616-637.

Esri, 2015, Independent Report Highlights Esri as Leader in Global GIS Market. Retrieved May 3, 2020, from https://www.esri.com/about/newsroom/announcements/indepen dent-report-highlights-esri-as-leader-in-global-gis-market/

Esri Classic Story Maps, 2020, Esri Classic Story Maps. Retrieved May 3, 2020, from https://storymapsclassic.arcgis.com/

Huchzermeyer, M., Karam, A., 2006. Informal Settlements: A Perpetual Challenge? Juta and Company Ltd.

Köbben, B., Yaman, M., 1996. Evaluating Dynamic Visual Variables. In Proceedings of the Seminar on Teaching Animated Cartography, edited by FJ Ormeling, B Köbben, and R Perez Gomez, pp. 45-51. Utrecht, The Netherlands: International Cartographic Association.

Kostof, S., 1993. The City Shaped: Urban Patterns and Meanings Through History. Bulfinch.

Mapbox, 2020, Mapbox. Retrieved May 3, 2020, from https://www.mapbox.com

McCall, M. and Dunn, C., 2012, Geo-information tools for participatory spatial planning: Fulfilling the criteria for 'good' governance?, Geoforum, 43(1), 81-94.

Marais, L. and Ntema, J., 2013, The upgrading of an informal settlement in South Africa: Two decades onwards. Habitat International, 39, 85-95.

Mason, S., Baltsavias, E., Bishop, I., 1997. Spatial Decision Support Systems for the Management of Informal Settlements. Computers, Environment and Urban Systems 21 (3-4): pp. 189208.

McCall, M. and Dunn, C., 2012, Geo-information tools for participatory spatial planning: Fulfilling the criteria for 'good' governance?, Geoforum, 43(1), 81-94.

Rambaldi, G., Chambers, R., McCall, M. and Fox, J., 2006, Practical ethics for PGIS practitioners, facilitators, technology intermediaries and researchers, Participatory learning and action, 54, 107-114. 
Rautenbach, V., Bevis, Y., Coetzee, S., Combrinck, C., 2015. Evaluating Procedural Modelling for 3D Models of Informal Settlements in Urban Design Activities. South African Journal of Science 111 (11/12): pp. 1-10.

Rautenbach, V., Coetzee, S., Coltekin, A., 2016. Investigating the use of 3D geovisualizations for urban design in informal settlement upgrading in South Africa. International Archives of the Photogrammetry, Remote Sensing and Spatial Information Sciences, Volume XLI-B2, 2016 XXIII ISPRS Congress, 12-19 July 2016, Prague, Czech Republic

Scott, M., Edwards, S., Rahall, N.J., Nguyen, T., and Cragle, J., 2016: GIS Story Maps: A Tool to Empower and Engage Stakeholders in Planning Sustainable Places. Charlottesville, VA.

Sheehan,M., 2013, GIS Have Never Been More Affordable. GeoInformatics, 16(8), 26. 